\title{
CORPORATE SOCIAL RESPONSIBILITY (CSR)DISCLOSURE AND THE IMPLICATIONS OFEARNING RESPONSE COEFFICIENT (ERC)
}

\author{
Rusdin \\ Departement of Business Administration Science \\ Padjadjaran University \\ Email: rusdin@unpad.ac.id
}

\begin{abstract}
One of the reasons is social management reporting for strategic reasons. Although it is not yet compulsory, but it can be said that almost all the companies listed on the Indonesian Stock Exchange already disclose information about CSR in its annual report in diverse levels. The purpose of the study is to examine the effect of the information of Corporate Social Responsibility disclosed in the companies' annual reports on the informativeness of earnings (measured by earning response coefficient, ERC). The study hypothesized that there is negative effect of CSR disclosures level on the ERC since the CSR disclosures provide investors more information which is not captured by the accounting earnings. The sample of the study consist of 135 annual reports 2013 and 2014 of the companies listed at the Indonesia Stock Exchange. The empirical results of the study show that the level of CSR disclosures has negative effect on the ERC as predicted. The results of the study indicate that investors assess the CSR information disclosed by the companies in their annual reports for their investment decision.
\end{abstract}

Keywords : corporate social responsibility, disclosure, earnings response coefficient

\section{PENGUNGKAPAN CORPORATE SOCIAL RESPONSIBILITY (CSR) DAN IMPLIKASINYA TERHADAP EARNING RESPONSE COEFFICIENT (ERC)}

\begin{abstract}
ABSTRAK
Salah satu alasan manajemen melakukan pelaporan sosial adalah untuk alasan strategis. Meskipun belum bersifat wajib, tetapi dapat dikatakan bahwa hampir semua perusahaan yang terdaftar di Bursa Efek Indonesia (BEI) sudah mengungkapkan informasi mengenai CSR dalam laporan tahunannya dalam kadar yang beragam. Tujuan dari penelitian ini adalah untuk menguji pengaruh informasi dari Corporate Social Responsibility (CSR) yang diungkapkan dalam laporan tahunan perusahaan terhadap keinformatifan laba yang diukur melalui koefisien respon laba (Earning Response Coefficient/ERC). Hipotesis penelitian ini bahwa terdapat pengaruh negatif tingkat pengungkapan CSR terhadap ERC,ketika investor mendapatkan informasi CSR yang diungkapkan oleh perusahaan dalam laporan tahunan untuk keputusan investasi mereka yang tidak direspon oleh laba akuntansi. Sampel penelitian ini terdiri dari 135 laporan tahunan 2013 dan 2014 dari perusahaan yang terdaftar di Bursa Efek Indonesia. Hasil empiris dari penelitian ini menunjukkan bahwa tingkat pengungkapan CSR memiliki efek negatif terhadap ERC seperti yang diperkirakan. Hasil penelitian menunjukkan bahwa investor menilai informasi CSR yang diungkapkan oleh perusahaan dalam laporan tahunan mereka untuk keputusan investasi mereka.
\end{abstract}

Kata kunci : tanggungjawab sosial perusahaan, pengungkapan, koefisien respon laba 


\section{PENDAHULUAN}

Jumlah perusahaan yang melakukan pengungkapan informasi pertanggungjawaban sosial (corporate social responsibility/CSR) dalam laporan tahunannya semakin bertambah dari waktu ke waktu, demikian juga dengan jumlah dan jenis informasi CSR yang diungkapkan semakin meningkat (Pang, 1982; Guthrie, 1982; Gray, 1990; Gray et al, 1993; Sayekti, 1994; Kroyan, 2006). Perusahaan semakin menyadari pentingnya implementasi program CSR sebagai bagian dari strategi bisnisnya. Hasil kajianThe Economist Intelligence Unit menunjukkan bahwa $85 \%$ eksekutif senior dan investor dari berbagai organisasi menjadikan CSR sebagai pertimbangan utama dalam pengambilan keputusan (EIU, 2015). Salah satu alasan manajemen melakukan pelaporan sosial adalah untuk alasan strategis. Meskipun belum bersifat compulsory, tetapi dapat dikatakan bahwa hampir semua perusahaan yang terdaftar di Bursa Efek Indonesia (BEI) sudah mengungkapkan informasi mengenai CSR dalam laporan tahunannya dalam kadar yang beragam (ICMD, 2015).

Dari perspektif ekonomi, perusahaan akan mengungkapkan suatu informasi jika informasi tersebut akan meningkatkan nilai perusahaan (Verecchia, 1983). Dengan implementasi CSR, diharapkan perusahaan akan memperoleh legitimasi sosial dan memaksimalkan kekuatan keuangannya dalam jangka panjang (Kiroyan, 2006). Hal ini mengindikasikan bahwa perusahaan yang menerapkan CSR mengharapkan akan direspon positif oleh para pelaku pasar. Literatur mengenai pengungkapan sukarela yang ada memberikan pemahaman bahwa pengungkapan informasi tersebut digunakan dalam penilaian perusahaan dan corporate finance (Core, 2001).

Hasil penelitian empiris mengenai hubungan antara returns/earnings menunjukkan bahwa meskipun informasi laba digunakan oleh investor, tetapi kegunaan dari informasi laba tersebut bagi investor sangat terbatas (Lev, 1989). Hal ini ditunjukkan dengan lemahnya dan tidak stabilnya contemporaneous korelasi antara return saham dan laba, dan juga rendahnya kontribusi laba untuk memprediksi harga dan return saham (Lev, 1989). Lev (1989) menyarankan agarpenelitian pasar modal menguji peranan dari pengukuran dalam penilaian aset, baik menyangkut aspek yang positif maupun yang normatif. Lev (1989) menyarankan agar penelitian lebih ditujukan pada pemahaman investor atas informasi yang terkandung dalam laporan keuangan (laporan tahunan) perusahaan. Model yang banyak digunakan hanya menghipotesiskan pada hubungan antara variabel finansial yang 'generic' (misalnya laba) dan nilai pasar, tetapi tidak memasukkan nature dari variabel lainnya (Lev, 1989).

Penelitian selanjutnya sudah banyak yang menguji variabel-variabel lain selain daripada laba, termasuk pengungkapan sukarela. Namun demikian, penelitian yang memasukkan komponen pengungkapan informasi CSR belum banyak diteliti. Berdasarkan hal tersebut, maka penelitian ini bertujuan untuk meneliti pengaruh dari tingkat pengungkapan informasi CSR dalam laporan tahunan terhadap informativeness of earnings (yang dalam hal ini diukur dengan Earning Response Coefficient, ERC).

Diharapkan bahwa investor mempertimbangkan informasi CSR yang diungkapkan dalam laporan tahunan perusahaan, sehingga dalam pengambilan keputusan investor tidak semata-mata mendasarkan pada informasi laba saja. Pengungkapan informasi CSR diharapkan memberikan informasi tambahan kepada para investor selain dari yang sudah tercakup dalam laba akuntansi. Dengan demikian, penelitian ini memprediksi bahwa pengaruh tingkat pengungkapan informasi CSR dalam laporan tahunan perusahaan terhadap ERC adalah negatif. Hal ini konsisten dengan prediksi yang dilakukan oleh Widyastuti (2002) yang memprediksi luas pengungkapan sukarela berpengaruh negatif terhadap ERC, namun tidak didukung oleh hasil penelitian empirisnya yang justru menunjukkan pengaruh yang positif dan signifikan.

Kelangsungan hidup perusahaan juga tergantung dari hubungan perusahaan dengan 
masyarakat dan lingkungannya tempat perusahaan beroperasi. Hal ini sejalan dengan legitimacy theory yang menyatakan bahwa perusahaan memiliki kontrak dengan masyarakat untuk melakukan kegiatannya berdasarkan nilainilai justice, dan bagaimana perusahaan menanggapi berbagai kelompok kepentingan untuk melegitimasi tindakan perusahaan (Haniffa et al, 2005). Jika terjadi ketidakselarasan antara sistem nilai perusahaan dan sistem nilai masyarakat, maka perusahaan dalam kehilangan legitimasinya, yang selanjutnya akan mengancam kelangsungan hidup perusahaan (Haniffa et al, 2005). Pengungkapan informasi CSR dalam annual report merupakan salah satu cara perusahaan untuk membangun, mempertahankan, dan melegitimasi kontribusi perusahaan dari sisi ekonomi dan politis (Guthrie dan Parker, 1990). Penelitian Basamalah et al (2005) yang melakukan review atas social and environmental reporting and auditing dari dua perusahaan di Indonesia, yaitu PT Freeport Indonesia dan PT Inti Indorayon, mendukung prediksi legitimacy theory tersebut.

Berbagai alasan perusahaan dalam melakukan pengungkapan informasi CSR secara sukarela telah diteliti dalam penelitian sebelumnya, diantaranya adalah karena untuk mentaati peraturan yang ada, untuk memperoleh keunggulan kompetitif melaluipenerapan CSR, untuk memenuhi ketentuan kontrak pinjaman dan memenuhi ekspektasi masyarakat, untuk melegitimasi tindakan perusahaan, dan untuk menarik investasor (Ullman, 1985; Patten, 1992; Deegan dan Blomquist, 2001).

Pengungkapan informasi CSR itu sendiri merupakan suatu hal yang bersifat endogeneous (Core, 2001; Healy dan Palepu, 2001). Berbagai penelitian terdahulu mengenai faktor-faktor determinan yang mempengaruhi perusahaan dalam melakukan pengungkapan informasi CSR telah banyak dilakukan. Ukuran perusahaan, profitabilitas, dan profil industri berkorelasi positif dengan pengungkapan informasi CSR (Haniffa et al, 2005; Cowen et al, 1997; McGure et al, 1988; Roberts, 1992, Sembiring, 2005; Sayekti, 2006). Penelitian sebelumnya menemukan bahwa tingkat leverage juga berkorelasi dengan tingkat pengungkapan informasi CSR, meskipun hasilnya beragam. Roberts (1992) menemukan korelasi yang positif, sedangkan Sayekti (2006) menemukan korelasi yang negatif. Selanjutnya, Haniffa et al (2005) dan Sembiring (2005) tidak menemukan korelasi antara tingkat leverage dan pengungkapan CSR. Faktor-faktor corporate governance juga dikorelasikan dengan tingkat pengungkapan informasi CSR dalam laporan tahunan perusahaan. Ukuran dewan komisaris, ukuran komite audit, kualitas auditor eksternal, dan struktur kepemilikan berkorelasi positif dengan pengungkapan CSR (Haniffa et al, 2005; Sembiring, 2005; Anggraini, 2006; Sayekti, 2006).

Laba diyakini sebagai informasi utama yang disajikan dalam laporan keuangan perusahaan (Lev,1989). Pertanyaan seberapa jauh kegunaan laba bagi para penggunalaporan keuangan menjadi hal yang penting baik bagi para peneliti, praktisi, dan juga otoritas pembuat kebijakan. Banyak model equity valuation yang hanya menggunakan expected earnings sebagai variabel eksplanatori (Lev, 1989). Namun demikian, earnings itu sendiri memiliki keterbatasan yang mungkin dipengaruhi oleh asumsi perhitungan dan juga kemungkinan manipulasi yang dilakukan oleh manajemenperusahaan, sehingga dibutuhkan informasi lain selain laba untuk memprediksi return saham perusahaan.

Scott (2000:152) mendefinisikan earnings response coefficient (ERC) sebagai berikut: An earnings response coefficient measures the extent of a security's abnormal market return in response to the unexpected component of reported earnings of the firm issuing that security. Terdapat beberapa hal yang menyebabkan respon pasar yang berbeda-beda terhadap laba, yaitu adalah persistensi laba, beta, struktur permodalan perusahaan, kualitas laba,growth opportunities, dan informativeness of price (Scott, 2000). Nilai ERC diprediksi lebihtinggi jika laba perusahaan lebih persisten di masa depan. Demikian juga jika kualitas laba semakin baik, maka diprediksi nilai ERC akan 
semakin tinggi. Beta mencerminkan risiko sistematis. Investor akan menilai laba sekarang untuk memprediksi laba dan return di masa yang akan datang.

Hubungan antara tingkat pengungkapan informasi yang dilakukan oleh perusahaan dengan kinerja pasar perusahaan masih sangat beragam. Secara teoretis, ada hubungan positif antara pengungkapan (termasuk pengungkapan sukarela) dan kinerja pasar perusahaan (Lang \& Lundholm, 1993). Laporan tahunan adalah salah satu media yang digunakan oleh perusahaan untuk berkomunikasi langsung dengan para investor. Pengungkapan informasi dalam laporan tahunan yang dilakukan oleh perusahaan diharapkan dapat mengurangi asimetri informasi dan juga mengurangi agency problems (Healy et al, 2001).

Berbagai penelitian telah menguji perbedaan ERC terhadap pengumuman laba dengan didasarkan pada premis bahwa informativeness of earnings akan semakin besar ketika terdapat ketidakpastian mengenai prospek perusahaan di masa datang (Widiastuti, 2006). Hal ini berarti bahwa semakin tinggi ketidakpastian prospek perusahaan di masa datang, maka ERC semakin tinggi. Diharapkan jika perusahaan melakukan pengungkapan informasi dalam laporan tahunannya dapat mengurangi ketidakpastian tersebut. Dengan demikian pengungkapan informasi akan menurunkan ERC.

Penelitian Lang dan Lundholm mengenai pengungkapan sukarela menunjukkan bahwa tingkat pengungkapan yang lebih tinggi berasosiasi dengan kinerja pasar yang lebih baik (yang diukur dengan return saham). Lang et al (1993) menggunakan korelasi laba dan return saham perusahaan sebagai proksi asimetri informasi. Hal ini konsisten dengan motif adverse selection (Lang et al, 1993). Korelasi laba dan return saham yang rendah mengindikasikan bahwa informasi laba hanya memberikan sedikit informasi tentang nilai perusahaan yang menunjukkan bahwa masih terdapat asimetri informasi yang tinggi. Pengungkapan tersebut bertujuan mengurangi asimetri informasi terutama pada perusahaan yang memiliki korelasi earning/returns yang rendah. Dengan demikian, Lang et al (1993) menyatakan adanya hubungan negatif antara korelasi earnings/returns (ERC) dengan tingkat pengungkapan.

Penelitian mengenai pengungkapan informasi CSR dalam annual report dan return saham perusahaan sudah banyak dilakukan, namun hasilnya masih beragam. Penelitian empiris awal sudah dilakukan oleh Spicer (1978) yang meneliti mengenai asosiasi antara investment value dari saham perusahaan dan kinerja sosial perusahaan. Spicer (1978) menemukan bukti empiris yang menunjukkan adanya asosiasi yang signifikan antara kedua hal tersebut meskipun tingkat asosiasi dari tahun ke tahun menurun. Hasil penelitian empiris ini konsisten dengan persepsi investor bahwa ada asosiasi antara investment value dari saham perusahaan dan kinerja sosialnya. Spicer (1978) menyarankan untuk dilakukan penelitian lanjutan agar dapat dilakukan generalisasi atas hasil penelitian ini.

Hasil penelitian Suratno et al (2006) menunjukkan bahwa environmental performance berpengaruh secara positif terhadap economic performance. Meskipun penelitian initidak secara langsung meneliti mengenai korelasi dari pengungkapan environmental terhadap kinerja ekonomi perusahaan, tetapi hasil penelitian ini menunjukkan bahwa environmental performance berpengaruh positif terhadap environmental disclosures. Hal ini mengindikasikan bahwa environmental disclosures berkorelasi positif dengan economic performance. Penelitian ini mengukur environmental disclosures dengan mengidentifikasi delapan (8) item pengungkapan dengan metode content analysis. Environmental performance diukur dari prestasi perusahaan dalam mengikuti program PROPER yang diselenggarakan oleh Kementerian Lingkungan Hidup (KLH). Sedangkan economic performance dalam penelitian ini diukur dengan return tahunan perusahaan relatif terhadap return industri.

Zuhroh dan Sukmawati (2003) melakukan pengujian empiris untuk mengetahui pengaruh dari luas pengungkapan sosial terhadap reaksi investor yang dicerminkan melalui volume perdagangan saham perusahaan yang 
dikategorikan dalam industri high profile. Zuhroh et al (2003) menemukan bahwa pengungkapan sosial dalam laporan tahunan perusahaan berpengaruh terhadap volume perdagangan saham bagi perusahaan yang masuk kategori high profile.

Lutfi (2001) tidak menemukan pengaruh yang signifikan dari praktek pengungkapan sosial yang dilakukan perusahaan terhadap perubahan harga saham. Hasil ini konsisten dengan Indah (2001), dan Rasmiati (2002) yang juga tidak menemukan hubungan yang signifikan antara pengungkapan sosial dengan volume perdagangan saham seputar publikasi laporan tahunan. Namun demikian, penelitian ini menemukan angka korelasi yang bernilai positif yang mengindikasikan bahwa informasi sosial yang diungkapkan perusahaan dalam laporan tahunan direspon baik oleh investor.

Penelitian yang menguji mengenai pengaruh pengungkapan dalam annual report terhadap ERC dilakukan oleh Widiastuti (2002), mengungkap pengaruh luas pengungkapan sukarela dalam annual report terhadap Earning Response Coefficient (ERC). Penelitian ini tidak menunjukkan hasil yang konsisten dengan prediksi tentang pengaruh luas pengungkapan sukarela dalam laporan tahunan terhadap ERC. Prediksi penelitian ini adalah bahwa ada luas pengungkapan sukarela berpengaruh negatif terhadap ERC. Namun demikian, pengujian empiris justrumenemukan adanya pengaruh positif signifikan dari luas pengungkapan sukarela terhadap ERC. Kemungkinan penjelasan atas hasil penelitian ini karena investor tidak cukup yakin dengan informasi sukarela yang diungkapkan manajemen sehingga investor tidak menggunakan informasi tersebut sebagai dasar untuk merevisi belief (Widiastuti, 2002). Kemungkinan penjelasan kedua yamg disebutkan Widiastuti (2002) adalah bahwa informasi sukarela yang diungkapkan perusahaan tidak cukup memberikan informasi tentang expected future earnings sehingga investor tetap akan menggunakan informasi laba sebagai proksi expected future earnings.
Berdasarkan uraian tersebut, secara teoretis yang ditunjukkan oleh berbagai hasil penelitian, dapat digambarkan model penelitian ini sebagai berikut:

Model I $:$ CAR $=\beta_{0}+\beta_{1} \mathrm{UE}+\beta_{2} \mathrm{CSRI}+$

$\beta_{3} \mathrm{UE}^{*} \mathrm{CSRI}+\varepsilon$

Model II : CAR $=\beta_{0}+\beta_{1} \mathrm{UE}+\beta_{2} \mathrm{CSRI}+$

$\beta_{3} \mathrm{BETA}+\beta_{4} \mathrm{PBV}+\beta_{5} \mathrm{UE} * \mathrm{CSRI}+\beta_{6} \mathrm{UE}^{*} \mathrm{BETA}$

$+\beta_{7} \mathrm{UE} * \mathrm{PBV}+\varepsilon$

Dari model penelitian tersebut memberikan hasil yang beragam mengenai asosiasi antara informasi CSR (termasuk lingkungan dan juga human capital), yang umumnya bersifat sukarela, yang diungkapkan perusahaan dalam laporan tahunannya dengan kinerja pasar. Secara umum, hasil-hasil penelitian empiris di atas mengindikasikan adanya apresiasi pasar terhadap informasi CSR yang diungkapkan perusahaan dalam laporan tahunannya. Namun demikian, pengaruh dari pengungkapan informasi CSR terhadap ERC belum banyak dilakukan.

Merujuk hasil penelitiansebelumnya, maka hipotesis yang diajukan dalam penelitian ini adalah: Tingkat pengungkapan informasi CSR dalam annual reportberimplikasinegatif terhadap Earning Response Coefficient (ERC).

Penelitian ini bertujuan untuk menguji pengaruh dari pengungkapan informasi Corporate Social Responsibility (CSR) dalam laporan tahunan perusahan terhadap respon pasar terhadap laba perusahaan (earning response coefficient, ERC).

Manfaat dari penelitian ini, bahwa hasil pengujian empiris ini dapat memberikan masukan bagi badan penyusun standar akuntansi dan badan otoritas pasar modal mengenai relevansi dari pengungkapan informasi CSR dalam Annual Report. Hal ini selanjutnya dapat menjadi masukan dalam mempertimbangkan apakah informasi CSR sudah waktunya diungkapkan dalam annual report atau tidak. 


\section{METODE PENELITIAN}

Metode yang digunakan dalam penelitian ini Metode Survei Penjelasan (Explanatory Survei Method). Bertujuan untuk menguji hipotesis yang telah dirumuskan sebelumnya. Walaupun uraiannya juga mengandung deskripsi, tetapi sebagai penelitian kuantitatif fokusnya terletak pada penjelasan hubungan antar variabel. Konsekuensi penelitian ini diperlukan operasionalisasi variabel yang lebih mendasar kepada indikator-indikatornya. Sesuai dengan hipotesis yang diajukan, dalam penelitian ini menggunakan analisis regresi berganda dengan metode regresi ordinary least square (OLS) cross-sectional dengan memasukkan variabel beta (sebagai proksi risiko) dan price-to-book value (sebagai proksi dari growth opportunities).

Variabel Cummulative Abnormal Return (CAR) berkedudukan sebagai variabel Dependen. Penentuan window (time interval) untuk mengukur cummulative abnormal return (CAR) saham perusahaan merupakan hal yang penting. Jika terlalu pendek, maka ukuran CAR tidak akan dapat menangkap reaksi pasar yang mungkin terjadi di luar window tersebut, misalnya karena reaksi investor yang lambat (Lev, 1989). Sebaliknya, jika time interval terlalu panjang, maka dapat memberikan pengukuran yang bias mengenai kontribusi informasi yang diungkapkan oleh perusahaan (Lev, 1989).

Unit analisis dilakukan meliputi 135 Annual Report Perusahaan Manufaktur (2015). Pengujian empiris atas unit analisis tersebut menunjukkan bahwa tingkat pengungkapan informasi CSR berimplikasi negatif terhadap besarnya ERC. Hal ini mendukung hipotesis yang diajukan, yang mengindikasikan bahwa investor mengapresiasi informasi CSR yang diungkapkan perusahaan dalam annual report untuk pengambilan keputusan investasi.

Variabel Cummulative Abnormal Return (CAR) dihitung secara harian untuk periode 24 bulan, yaitu periode 1Januari 2013 sampai 31 Desember 2014. Pengukuran abnormal return dalam penelitian ini menggunakan marketadjusted model yang mengasumsikan bahwa pengukuran expected return saham perusahaan yang terbaik adalah return indeks pasar (Pincus, 1993, dalam Widiastuti, 2002; Junaedi, 2005). Berikut adalah rumus untuk menghitung abnormal return:

$$
\begin{gathered}
\mathrm{R}_{\mathrm{it}}=\frac{P_{i t}-P_{i t}}{P_{i t}-1} \\
\mathrm{R}_{\mathrm{mt}}=\frac{\mathrm{IHSG}_{\mathrm{t}}-\mathrm{IHSG}}{\mathrm{IHSG}_{\mathrm{t} \_1}} \\
\mathrm{AR}_{\mathrm{it}} \mathrm{R}_{\mathrm{it}}-\mathrm{R}_{\mathrm{mt}}
\end{gathered}
$$

Dimana:

$\mathrm{AR}_{\mathrm{it}}$ : Abnormal return untuk perusahaan i pada hari ke-t.

$\mathrm{R}_{\text {it }}$ : Return harian perusahaan i pada hari ke-t.

$\mathrm{R}_{\mathrm{m}}$ : Return indeks pasar pada hari ke-t.

$\mathrm{P}_{\text {it }}$ : Harga saham perusahaan i pada waktu t.

$\mathrm{P}_{\text {it-1 }}$ : Harga saham perusahaan I pada waktu t-1.

IHSG $_{t}$ : Indeks Harga Saham Gabungan pada waktu t.

IHSG $_{\mathrm{t}-1}$ : Indeks Harga Saham Gabungan pada waktu $\mathrm{t}-1$.

Selanjutnya, perhitungan CAR untuk masingmasing perusahaan merupakan akumulasi abnormal return dari masing-masing perusahaan tersebut selama periode 24 bulan.

Variabel Unexpected Earnings (UE) dan pengungkapan informasi CSR dalam annual report perusahaan atau CSR disclosure Indeks (CSRI). Dengan asumsi random walk, variabel UE dihitung sebagai perubahan dari laba per saham perusahaan sebelum pos luar biasa tahun sekarang dikurangi dengan laba per saham perusahaan sebelum pos luar biasa tahun sebelumnya, dan diskalakan dengan harga per lembar saham pada akhir periode sebelumnya (Kothari \& Zimmerman, 1995; Billings, 1999; Widiastuti, 2002). Jadi, dalam penelitian ini variabel UE dihitung dari laba per saham (sebelum pos luar biasa) tahun 2014 dikurangi dengan laba per saham perusahaan (sebelum pos 
luar biasa) tahun 2013, dan dibagi dengan harga per lembar saham pada 31 Desember 2013.

Mengacu pada penelitian Hanifa.,et., al (2005), maka pengukuran variabel CSRI menggunakan content analysis yang mengukur variety dari CSRI. Content analysis adalah salah satu metode pengukuran CSRI yang sudah banyak digunakan dalam penelitian-penelitian sebelumnya. Lindenmann (1983) mendefinisikan content analysis sebagai berikut:A means for taking messages that are conveyed as part of the communication process, coding and classifying them as precisely and objectively as possible and then summarizing and explaining them quantitatively.

Instrumen pengukuran CSRI yang digunakan dalam penelitian ini mengacu pada pengelompokkan informasi CSR ke dalam kategori: Lingkungan, Energi, Tenaga Kerja, Produk, KeterlibatanMasyarakat, dan Umum. Total item CSR berkisar antara 63 sampai dengan 79, tergantung dari jenis industri perusahaan termasuk unit analisis.

Pendekatan untuk menghitung CSRI pada dasarnya menggunakan pendekatan dikotomi, yaitu setiap item CSR dalam instrumen penelitian diberi nilai 1 jika diungkapkan, dan nilai 0 jika tidak diungkapkan (Haniffa, et., al., 2005). Selanjutnya, skor dari setiap item dijumlahkan untuk memperoleh keseluruhan skor untuk setiap perusahaan. Rumus perhitungan CSRI (Haniffa et al, 2005), sebagai berikut:

$$
\operatorname{CSRI}_{j} \frac{\sum X_{i j}}{n j}
$$

Keterangan:

\section{$\mathrm{CSRI}_{\mathrm{j}}$ : Corporate Social Responsibility}

Disclosure Index perusahaan $\mathrm{j}$

$\mathrm{n}_{\mathrm{j}}$ : jumlah item untuk perusahaan $\mathrm{j}, \mathrm{n}_{\mathrm{j}} \leq 79$

$\mathrm{X}_{\mathrm{ij}}$ : dummy variable: $1=$ jika item $\mathrm{i}$

diungkapkan; 0 = jika item $\mathrm{i}$ tidak diungkapkan

Dengan demikian, $0 \leq \mathrm{CSRI}_{\mathrm{j}} \leq 1$

Selanjutnya, untuk melihat pengaruh dari CSRI terhadap ERC, maka variabel UE dan variabel CSRI akan diinter-aksi-kan dalam persamaan regresi dengan model interaksi.

\section{Control Variables}

Meskipun ada beberapa variabel yang diprediksi dapat mempengaruhi respon pasar terhadap laba, tetapi penelitian ini hanya menggunakan dua variabel kontrol, yaitu BETA (yang memproksi risiko) dan Price-to-BookValue (PBV, yang memproksi growth opportunities). BETA diprediksi akan berpengaruh negatif terhadap ERC, sedangkan PBV diprediksi akan berpengaruh positif terhadap ERC (Scott, 2000).

Guna menguji hipotesis digunakan alat uji analisis regresi berganda dengan model interaksi yaitu: metode ordinary least square (OLS) crosssectional. Terdapat dua model yang diajukan, yaitu model pertama yang meregresikan variabel CAR dengan variabel UE dan CSRI, serta interaksi keduanya, tanpa memasukkan variabel kontrol. Model kedua adalah model yang sudah memasukkan variabel kontrol (yaitu BETA, dan PBV) berserta interaksi dari masing-masing variabel kontrol tersebut dengan variabel UE.

Jika tingkat pengungkapan informasi CSR mempengaruhi informativeness dari earnings atau jika informasi CSR mempengaruhi ERC, maka diprediksi koefisien interaksi antara variabel UE dan CSRI ( $\beta_{3}$ pada Model I dan $\beta_{5}$ pada Model II) dari Model I akansignifikan dan bertanda negatif. Sedangkan untuk melihat pengaruh variabel kontrol (BETA, dan PBV) terhadap ERC, maka berturut-turut dilihat signifikansi dan arah dari koefisien $\beta_{6}$, dan $\beta_{7}$ pada Model II.

Penelitian ini menggunakan data sekunder yang diperoleh dari annual reportper 31 Desember 2013 dan 2014pada Industri Manufaktur yang terdaftar di Bursa Efek Indonesia, untuk melakukan penghitungan indeks CSR. Selanjutnya, data harga saham untuk menghitung return perusahaan, return pasar, serta data beta diperoleh dari situs Bursa Efek Indonesia (http://www.idx.co.id/), Indonesian Capital Market Directory 2015. Dari 312 perusahaan yang terdaftar di BEIsampai dengan tahun 2014, maka penelitian ini menggunakan 135 sampel perusahaan, yang terdiri dari berbagai industry manufaktur. 
Perhitungan Unexpected Earnings (UE) menggunakan asumsi random walk seperti yang juga banyak digunakan dalam penelitian sebelumnya (Ali, 1994). Variabel UE dihitung sebagai perubahandari laba per saham perusahaan sebelum pos luar biasa tahun sekarang dikurangi dengan laba per saham perusahaan sebelum pos luar biasa tahun sebelumnya, dan diskalakan dengan harga per lembar saham pada akhir periode sebelumnya. Jadi, dalam penelitian ini variabel UE dihitung dari laba per saham (sebelum pos luar biasa) tahun 2014 dikurangi dengan laba per saham perusahaan (sebelum pos luar biasa) tahun 2013, dan dibagi dengan harga per lembar saham pada 31 Desember 2013.

\section{HASIL DAN PEMBAHASAN}

Deskripsi 135 perusahaan yang diteliti menunjukkan angka statistik seperti terlihat pada Tabel 1 sebagai berikut:

Tabel 1. Deskriptif Masing-Masing Variabel

\begin{tabular}{lcrrrr}
\hline \multicolumn{1}{c}{ Variabel } & $\mathrm{N}$ & \multicolumn{1}{c}{ Minimum } & \multicolumn{1}{c}{ Maximum } & \multicolumn{1}{c}{ Mean } & \multicolumn{2}{c}{ Std. Deviation } \\
\hline CAR & 135 & -1.405 & 2.5877 & .0808 & .7130 \\
UE & 135 & -1.677 & 8.1150 & .0199 & 1.5315 \\
CSRI & 135 & .0256 & .5128 & .2017 & .1188 \\
BETA & 135 & -.8828 & .89 & .0830 & .3258 \\
\hline PBV & 135 & -1.56995 & 42.04 & 1.561327 & 4.296528 \\
\hline
\end{tabular}

Hasil pengujian Pearson correlation antara variabel-variabel yang diteliti dapat dilihat pada Tabel 2 berikut ini:

Tabel 2. Pearson Correlation antara Variabel-Variabel Penelitian

\begin{tabular}{|c|c|c|c|c|c|c|c|c|}
\hline & CA R & UE & CSRI & BETA & PBV & UE*CSRI & UE*BETA & UE*PBV \\
\hline CAR & 1.000 & $\begin{array}{c}0.024 \\
(0.441)\end{array}$ & $\begin{array}{c}0.205 \\
(0.016)\end{array}$ & $\begin{array}{l}-0.041 \\
(0.335)\end{array}$ & $\begin{array}{c}0.089 \\
(0.181)\end{array}$ & $\begin{array}{c}0.082 \\
(0.199)\end{array}$ & $\begin{array}{l}-0.201 \\
(0.018)^{*}\end{array}$ & $\begin{array}{c}0.212 \\
(0.014)^{*}\end{array}$ \\
\hline UE & & 1.000 & $\begin{array}{l}0.019 * * \\
(0.425)\end{array}$ & $\begin{array}{r}-0.205 \\
(0.017)\end{array}$ & $\begin{array}{c}0.024 \\
(0.401)\end{array}$ & $\begin{array}{c}0.906 \\
(0.000)^{*}\end{array}$ & $\begin{array}{c}0.760^{*} \\
(0.000)^{*}\end{array}$ & $\begin{array}{c}0.218^{*} \\
(0.012)^{*}\end{array}$ \\
\hline CSRI & & & 1.000 & $0.082^{* *}$ & 0.218 & $0.012 * *$ & $0.049^{* *}$ & 0.105 \\
\hline BETA & & & & $\begin{array}{c}(0.200) \\
1.000\end{array}$ & $\begin{array}{c}(0.012) \\
0.064 \\
(0.254)\end{array}$ & $\begin{array}{c}(0.40) \\
-0.206 \\
(0.016) \\
* *\end{array}$ & $\begin{array}{c}(0.307) \\
-0.195 \\
(0.022) * *\end{array}$ & $\begin{array}{l}(0.140) \\
-0.089 \\
(0.180)\end{array}$ \\
\hline PBV & & & & & 1.000 & $\begin{array}{c}0.047 \\
(0.314)\end{array}$ & $\begin{array}{c}0.030 \\
(0.379)\end{array}$ & $\begin{array}{c}0.811 \\
(0.000)^{* *}\end{array}$ \\
\hline UE*CSRI & & & & & & 1.000 & $\begin{array}{c}0.475 \\
(0,000) \\
* * *\end{array}$ & $\begin{array}{c}0.292 \\
(0.001)^{* * *}\end{array}$ \\
\hline UE*BETA & & & & & & & 1.000 & $\begin{array}{c}0.006 \\
(0.477)\end{array}$ \\
\hline UE*PBV & & & & & & & & 1.000 \\
\hline
\end{tabular}


Hasil pengujian model regresi berganda baik untuk Model I maupun Model II dapat dilihat pada Tabel 3 berikut ini:

Tabel 3. Hasil Analisis Regresi Berganda

\begin{tabular}{|c|c|c|c|}
\hline \multirow{2}{*}{ Variabel dep: CAR } & Pred. Sign & Model I & Model II \\
\hline & & $\begin{array}{c}\text { Koef. } \\
(\mathrm{p}-\text { value })\end{array}$ & $\begin{array}{c}\text { Koef. } \\
\text { (p-value })\end{array}$ \\
\hline \multirow[t]{4}{*}{ Constant } & & -0.3409 & -0.3903 \\
\hline & & $(0.0128) * *$ & $(0.0037) * * *$ \\
\hline & + & -0.16257 & 0.49842 \\
\hline & & $(0.1263)$ & $(0.0323) * *$ \\
\hline \multirow[t]{2}{*}{ CSRI } & & 1.2587 & 1.3849 \\
\hline & + & $(0.0309) * *$ & $(0.0164) * *$ \\
\hline BETA & + & & $\begin{array}{l}-0.0999 \\
-0.0202\end{array}$ \\
\hline PBV & + & & $(0.5244)$ \\
\hline UE*CSRI & - & $\begin{array}{c}1.2689 \\
(0.0825) *\end{array}$ & $\begin{array}{c}-1.93634 \\
(0.0869) *\end{array}$ \\
\hline UE*BETA & - & & $\begin{array}{c}-0.5226 \\
(0.0034) * * *\end{array}$ \\
\hline UE*PBV & - & & $\begin{array}{c}0.1158 \\
(0.2387)\end{array}$ \\
\hline $\mathrm{R}^{2}$ & & $0.070+$ & 0.2013 \\
\hline Adj. $R^{2}$ & & 0.0429 & 0.1454 \\
\hline $\mathrm{F}$ & & 2.601 & 3.6023 \\
\hline $\mathrm{p}$-value & & $0.056^{*}$ & $0.00168 * * *$ \\
\hline Durbin-Watson & & 1.7888 & 1.6883 \\
\hline
\end{tabular}

$*$ Signifikan pada $=10 \% ; * *$ Signifikan pada $=5 \% ; * * *$ Signifikan pada $=1 \%$

Tabel 3 di atas menyajikan dua model regresi berganda, yaitu Model I yang tidakmemasukkan variabel kontrol, dapat dibuat persamaan modelnya sebagai berikut:

Model I $:$ CAR $=-.3409-.163 \mathrm{UE}+1.258 \mathrm{CSRI}+1.2668 \mathrm{UE} * \mathrm{CSRI}+\varepsilon$

Demikian halnya dengan Model II yang memasukkan variabel control, dapat dilihat sebegai berikut:

Model II $:$ CAR $=-.390+.498 \mathrm{UE}+1.384 \mathrm{CSRI}-$ $.099 \mathrm{BETA} \quad-\quad .020 \mathrm{PBV} \quad-1.36 \mathrm{UE}{ }^{*} \mathrm{CSRI}-$ $.522 \mathrm{UE}^{*} \mathrm{BETA}+.1158 \mathrm{UE} * \mathrm{PBV}+\varepsilon$

Uji F dari kedua model regresi tersebut menunjukkan hasil yang signifikan. Model I memiliki nilai uji F sebesar 2,601 (sig 0,056), dan Model II memiliki nilai uji F sebesar 3,6024 (sig 0,002). Hal ini berarti bahwa kedua model tersebut baik model regresi yang tanpa variabel kontrol maupun yang dengan variabel kontrol dapat menjelaskan variasi dari variabel dependen, yaitu CAR. Namun demikian, hasil uji F Model II menunjukkan hasil yang lebih baik dibandingkan dengan hasil uji Model I. Hal ini dapat dilihat dari signifikansi Model I pada tingkat keyakinan $90 \%(\alpha-0,01)$, sedangkan Model II menunjukkan signifikansi yang lebih baik, yaitu signifikan pada tingkat $90 \%(\alpha-0,01)$.

Hasil pengujian regresi menunjukkan bahwa Model I memiliki adjusted square sebesar 0,0042, sedangkan Model II memiliki adjusted squareyang lebih baik, yaitu 0,1455 . Hal ini sesuai dengan penelitian terdahulu, bahwa respon pasar terhadap laba dipengaruhi oleh beberapa faktor, diantaranya adalah beta dan growth opportunities (yang dalam penelitian ini masingmasing diproksi dengan variabel BETA dan 
PBV). Peningkatan $\mathrm{R}^{2}$ tersebut (dari 0,0042 menjadi 0,1455) menunjukkan bahwa pengikutsertaan variabel kontrol meningkatkan explainability model atau explainability variabel independen terhadap perilaku variabel dependen (CAR). Jadi, dapatdisimpulkan bahwa kedua model adalah baik, namun Model II yang memasukkan kontrol adalah model jauh yang lebih baik.

Ketika variabel kontrol tidak dimasukkan dalam model (Model I), tampak bahwa variabel interaksi UE*CSRI signifikan pada tingkat $10 \%$, tetapi tanda koefisien positif (tidak sesuai dengan prediksi). Variabel CSRI menunjukkan estimasi koefisien yang positif dan signifikan pada tingkat 95\% ( $\alpha-0,05)$, sedangkan variabel UE tidak signifikan. Hasil pengujian Model I tidak dapat mendukung hipotesis yang diajukan dalam penelitian ini, yaitu bahwa tingkat pengungkapan informasi CSR berpengaruh negatif terhadap ERC. Hasil ini konsisten dengan temuan sebelumnya yang menguji pengaruh luas pengungkapan sukarela terhadap ERC.

Selanjutnya, hasil pengujian Model II yang memasukkan variabel kontrol menunjukkan hasil yang berbeda dengan pengujian Model I. Hasil pengujian Model II menunjukkan bahwa koefisien variabel interaksi UE*CSRI adalah negatif dan signifikan pada tingkat $10 \%$. Estimasi koefisien variabel UE dan variabel CSRI juga menunjukkan hasil yang signifikan positif pada tingkat $95 \%(\alpha-0,05)$. Hasil pengujian interaksi variabel UE dan variabel kontrol menunjukkan bahwa hanya interaksi variabel UE*BETA saja yang negatif dan signifikan sesuai dengan prediksi. Sedangkan interaksi variabel UE*PBV tidak menunjukkan hasil yang signifikan. Hasil pengujian Model II ini mendukung hipotesis yang diajukan bahwa pengungkapan informasi CSR dalam annual report perusahaan akan menurunkan ERC. Hal ini sesuai dengan asumsi bahwa informativeness of earnings akan semakin besar ketika terdapat ketidakpastian mengenai prospek perusahaan di masa datang. Diharapkan jika perusahaan melakukan pengungkapan informasi CSR dalam laporan tahunannya akan dapat mengurangi ketidakpastian tersebut. Dengan demikian pengungkapan informasi CSR tersebut akan menurunkan ERC. Hal ini mengindikasikan bahwa investor mengapresiasi informasi CSR yang diungkapkan perusahaan sebagai salah satu dasar pengambilan keputusan investasinya.

Hasil interaksi variabel UE dengan variabel kontrol BETA menunjukkan bahwa beta berpengaruh negatif terhadap ERC, yang berarti semakin perusahaan berisiko, maka ERC akan semakin rendah. Dapat dikatakan bahwa variabel kontrol memiliki pengaruh yang signifikan terhadap besaran ERC. Hasil pengujian Model II yang mendukung hipotesis tidak konsisten dengan temuan Widiastuti yang tidak menemukan pengaruh luas pengungkapan sukarela yang negatif terhadap ERC, meskipun sudah memasukkan seluruh kontrol variabel (yaitu beta, leverage, growth, persistensi laba, dan ukuran perusahaan). Dengan kata lain berdasarkan pengujian tersebut, hipotesis yang diajukan dalam penelitian ini yang menyatakan bahwa pengungkapan informasi CSR dalam laporan tahunan perusahaan berpengaruh negatif terhadap CSR didukung oleh data empiris dari sampel penelitian ini. Namun demikian, dalam menginterpretasi hasil penelitian ini tetap harus dipertimbangkan masalah multikolinearitas yang sudah disebutkan sebelumnya, karena ada kemungkinan estimasi koefisien bias meskipun hasil sesuai dengan hipotesis yang diajukan.

\section{SIMPULAN}

Berdasakan hasil penelitian dan pembahasan dapat dikemukakan kesimpulan bahwa pengungkapan informasi Corporate Social Responsibility dalam annual report 2013 dan 2014 pada industri manufakturyang telah melakukan emisi saham dengan memasukkan variabel beta (sebagai proksi risiko) dan price-tobook value (sebagai proksi dari growth opportunities) berimplikasi negatif terhadap Earning Response Coefficient (ERC). Hasil interaksi variabel UE dengan variabel kontrol BETA menunjukkan bahwa beta berimplikasi negatif terhadap ERC, yang berarti semakin perusahaan berisiko, maka ERC akan semakin 
rendah.Hasil penelitian ini mengindikasikan bahwa investor mengapresiasi informasi Corporate Social Responsibility (CSR) yang diungkapan dalam annual reportindustri manufaktur yang telah melakukan emisi saham. Hasil penelitian ini masi relevan dengan hasil penelitian sebelumnya, seperti asumsi bahwa informativeness of earnings akan semakin besar ketika terdapat ketidakpastian mengenai prospek perusahaan di masa datang.

\section{DAFTAR PUSTAKA}

Adam, Tim., dan Vidham K. Gigbeoyal 2003. The Investment Opportunity Set and its Proxy Variables: Theory and Evidence. Hongkong University of Science and Technolgy.

Alexander, Gordon J., and Rogene A. Buchholz, 1978. Corporate Social Responsibility and Stock Market Performance. The Academy of Management Journal, Vol. 21, No. 3 (Sep), pp. 479-486.

Basamalah, Anies S., and Johnny Jermias, 2005. Social and Environmental Reporting and Auditing in Indonesia: Maintaining Organizational Legitimacy?, Gadjah Mada International Journal of Business, JanuaryApril 2005, Vol. 7, No. 1, pp. 109 - 127.

Billings, Bruce K., 1999. "Revisiting the Relation between the Default Risk of Debt and the Earnings Response Coefficient", The Accounting Review, Vol. 74, No. 4. (Oct), pp. 509-522.

Bodie, Zvi, Alex Kane dan Alan J. Marcus. 2005. Investments. $6^{\text {th }}$ ed. McGraw-Hill.

Brealey and Myers. 2001. Principles of Corporate Finance. New York : McGraw Hill.

Brealey, Richard A., Stewart C. Myers., dan Franklin Allen. 2006. Corporate Finance. Mc Graw Hill Irwin.

Cowen, S., Ferreri, L.D., dan L.D. Parker, 1987. The Impact of Corporate Characteristics on Social Responsibility Disclosure: A Typology and Frequency-Based Analysis", Accounting, Organization and Society, Vol. 12, No. 2, pp. 111-122.
Damodaran, Aswath., 2004. Damodaran on Valuation: Security Analysis forInvestment and Corporate Finance. New York : John Wiley \& Sons, Inc,.

Gray, R.H. 1990, Corporate Social Reporting by UK Companies: A Cross-Sectional and Longitudinal Study an Interim Report. Draft/Working Paper.

Gray, Rob, Reza Kouhy, and Simon Lavers, 1993. Social and Environmental Reporting by UK Companies: A Longitudinal Study. A Tale of Two Samples. The Construction of a Research Database and An Exploration of the Political Economy Thesis, Unpublished paper.

Guthrie, J. and L.D. Parker, 1990, "Corporate Social Disclosure Practice: A Comparative International Analysis", Advances in Public Interest Accounting, Vol. 3, pp. 159-175.

Haniffa, R.M., dan T.E. Cooke, 2005, The Impact of Culture and Governance on Corporate Social Reporting, Journal of Accounting and Public Policy 24, pp. 391-430.

Healy, Paul M., and Krishna G. Palepu, 2001. Information asymmetry, corproate disclosure, and the capital markets: A review of the empirical disclosure literature, Journal of Accounting and Economics, 31, pp. 405-440.

Kiroyan, Noke, 2006. Good Corporate Governance (GCG) dan Corporate Social Responsibility (CSR) Adakah Kaitan di Antara Keduanya?", Economics Business Accounting Review, Edisi III, SeptemberDesember 2006, Hal. 45-58.

Kothari, S.P., and Jerold L. Zimmerman, 1995. Price and Return Models, Journal of Accounting and Economics, 20, pp.155-192.

Lang, Mark, and Lundholm Russell, 1993. CrossSectional Determinants of Analysts Rattings of Corporate Disclosures. Journal of Accounting Research, Vol. 31, No. 2 (Autumn), pp. 246-271.

Lev, Baruch, 1989. On the Usefulness of Earnings and Earnings Research: Lessons and Directions from Two Decades of 
Empirical Research.Journal of Accounting Research, Vol. 27, pp. 153-192.

Lindenmann, 1983. Content Analysis, Public Relations Journal, July 1983, pp. 24-26.

McGuire, J.B., A. Sundgren, and T. Schneeweis, 1988. "Corporate Social Responsibility and Firm Financial Performance, Academy of Management Journal, Vol. 31, No. 4, pp. 854-872.

Pang, Y.H. 1982. Financial Reporting: Disclosures of Corporate Social Responsibility, The Chartered Accountant in Australia, July, 1982, pp. 32-34.

Pfeiffer, Jr., Ray J., Pieter T. Elgers, May H. Lo, and Lynn L. Rees, 2001. Additional Evidence on the Incremental Information Content of Cash Flows and Accruals: The Impact of Errors in Measuring Market Expectations, The Accounting Review, vol. 73, No. 3 (Jul), PP. 373-385.

Roberts, R.W. 1992, Determinants of Corporate Social Responsibility Disclosures: An Application of Stakeholder Theory, Accounting, Organization and Society, Vol. 17, No. 6: 595-612.

Trotman, K.T., and G.W. Bradley, 1981. Associations between Social Responsibility Disclosure and Characteristics of Companies, Accounting, Organizations and Society, Vol. 6, No. 4, pp. 355-362.

Weston, J. Fred dan Eugene F. Bringham, 2003. $10^{\text {th }}$ edition. Essentials of Managerial Finance. New York: The Dryden Press. 